\title{
Transfer of Campylobacter pylori and Campylobacter mustelae to Helicobacter gen. nov. as Helicobacter pylori comb. nov. and Helicobacter mustelae comb. nov., Respectively
}

\author{
C. STEWART GOODWIN, ${ }^{1 *}$ JOHN A. ARMSTRONG, ${ }^{2}$ TERRY CHILVERS, ${ }^{1}$ MICHELLE PETERS, ${ }^{1}$ M. DAVID \\ COLLINS,${ }^{3}$ LINDSAY SLY,${ }^{4}$ WILLIAM MCCONNELL ${ }^{1}$ AND WILLIAM E. S. HARPER ${ }^{1}$ \\ Department of Microbiology ${ }^{1}$ and Department of Electron Microscopy, ${ }^{2}$ Royal Perth Hospital, Perth, Western Australia \\ 6001, Australia; Agricultural and Food Research Council, Institute of Food Research, Reading Laboratory, Shinfield, \\ Reading RG2 9AT, United Kingdom ${ }^{3}$; and Department of Microbiology, University of Queensland, \\ St. Lucia, Queensland 4067, Australia ${ }^{4}$
}

\begin{abstract}
Different types of studies have shown that Campylobacter pylori does not belong in the genus Campylobacter. Ribonucleic acid sequencing has indicated that $C$. pylori might belong in the genus Wolinella, but we describe five major groups of taxonomic features of the genus Wolinella that differ markedly from those of $C$. pylori, including ultrastructure and morphology, cellular fatty acids, menaquinones, growth characteristics, and enzyme capabilities, indicating that $C$. pylori should not be included in the genus Wolinella. Thus, we propose the establishment of a new genus, Helicobacter; $C$. pylori should be transferred to this genus as Helicobacter pylori comb. nov., and $H$. pylori NCTC 11637 (= ATCC 43504) is the type strain. The gastric spiral organism from ferrets has been elevated recently from Campylobacter pylori subsp. mustelae to Campylobacter mustelae. We describe the similarities and differences between $C$. mustelae and $C$. pylori compared with other campylobacters, and we propose that $C$. mustelae should be included in the new genus Helicobacter as Helicobacter mustelae comb. nov. (type strain, ATCC 43772).
\end{abstract}

In April 1982 in the Microbiology Department of Royal Perth Hospital, Perth, Western Australia, culture of endoscopic biopsy specimens of human gastric mucosa yielded a spiral organism with some features of the genus Campylobacter, which was named Campylobacter pyloridis (34). The specific epithet was grammatically incorrect, and the name was later corrected to Campylobacter pylori (33). However, in 1985 we reported that the cellular fatty acids and major ultrastructural features of $C$. pylori were very different from those of all other campylobacters, and this suggested that $C$. pylori did not belong in this genus (24). We also reported that methylated menaquinone 6 (MK-6), which is characteristic of all other campylobacters, is absent in C. pylori (22); in addition, the antibiotic susceptibilities of $C$. pylori are different from those of other campylobacters (20). C. pylori could not be included in the genus Spirillum, a genus which consists of rigid spiral organisms (24). Four studies of the $5 \mathrm{~S}$ and $16 \mathrm{~S}$ ribosomal ribonucleic acid sequences of $C$. pylori compared with those of other campylobacters indicated clearly that $C$. pylori should not be included in the genus Campylobacter $(28,38,41,44)$, but may be more closely related to Wolinella succinogenes. Thompson et al. (44) suggested that $C$. pylori should be placed in the genus Wolinella, but Romaniuk et al. (41) and Lau et al. (28) noted sufficient differences between $W$. succinogenes and $C$. pylori to justify separate genera. The Committee on Reconciliation of Approaches to Bacterial Systematics stated that "the depth in a ribonucleic acid dendrogram at which a given hierarchical line is to be drawn may vary along different major branches of the dendrogram and will be strongly influenced by phenotypic consistency at each level" (46). In this paper we describe marked phenotypic inconsistencies between $C$. pylori and $W$. succinogenes and delineate five major groups of taxonomic features of these bacteria (ultrastructural features, cellular fatty acid profiles, respiratory

\footnotetext{
* Corresponding author.
}

quinones, growth characteristics, and enzyme capabilities) which were also regarded as important by the Subcommittee for Taxonomy of Methanogenic Bacteria (3). Our data indicate that $C$. pylori should not be included in the genus Wolinella, but should be a member of a new genus.

Ribonucleic acid sequencing of "Flexispira rappini" has indicated a close relationship between this organisms and $C$. pylori (B. J. Paster, personal communication). "F. rappini" is not a spiral organism, but is urease positive. In this paper we describe the chemotaxonomic differences between $C$. pylori and " $F$. rappini," which confirm the original suggestion that " $F$. rappini" should not be in the same genus as $C$. pylori (J. H. Bryner, Campylobacter IV. Proc. 4th Int. Workshop Campylobacter Infect., p. 440-442, 1988).

From the stomachs of ferrets a spiral organism similar to C. pylori was isolated in Boston, Mass. (16). This organism was named Campylobacter pylori subsp. mustelae, because deoxyribonucleic acid (DNA)-DNA hybridization showed a relationship with $C$. pylori at the subspecies level (17). However, in Perth, our DNA-DNA hybridization studies yielded a much lower degree of homology, indicating a more distant relationship; this finding was subsequently confirmed by the original workers. Other important taxonomic features distinguish $C$. pylori and the ferret organism, and the latter organism has now been elevated to species status as Campylobacter mustelae (15).

C. pylori is an important human pathogen, causing type B gastritis of stomachs (13), and is probably a major predisposing cause of duodenal ulcers $(19,25) . C$. pylori gastritis is widespread in many countries in the world (31) and may be one of the most common chronic human infections. Thus, if $C$. pylori should not be in the genus Campylobacter, from the viewpoint of medicine there is great urgency in assigning a new genus name to this organism, so that the definitive name can become commonly used. This would also avoid the current confusion when reference is made to "campylobacter infections," which usually refer to diarrhoea due to 
Campylobacter jejuni and allied campylobacters and not to stomach symptoms due to $C$. pylori. Furthermore, similar spiral organisms have been found in the stomachs of the monkeys Macaca mulatta (36) and Macaca nemestrina (5), and in Perth we have recently isolated similar organisms from Macaca fascicularis and from Papio species (unpublished data). These bacteria are candidates for inclusion in the new genus, for which we propose the name Helicobacter. The name Helicobacter refers to the morphology of the organisms, which are helical in vivo but often rodlike in vitro; also, the name Helicobacter is euphonious and has the advantage that it is similar to the name Campylobacter.

In this paper we report the guanine-plus-cytosine $(\mathrm{G}+\mathrm{C})$ contents, DNA-DNA hybridization data, ultrastructural features, cellular fatty acid profiles, respiratory menaquinones, growth characteristics, and enzyme capabilities of members of the new genus Helicobacter and of the two species which we propose for it, Helicobacter pylori and Helicobacter mustelae.

\section{MATERIALS AND METHODS}

Bacterial strains and growth of stock cultures. $C$. pylori (designated $H$. pylori as a result of this study) NCTC $11637^{\mathrm{T}}$ ( $\mathrm{T}=$ type strain) was isolated in Perth, Australia, in 1982, where 69 other isolates were also obtained from human endoscopic specimens. Two isolates of $H$. pylori from the United Kingdom were supplied by F. J. Bolton, Public Health Laboratory, Preston, United Kingdom, and six isolates from the United States were provided by Donna Morgan, Norwich Eaton Pharmaceuticals, Norwich, N.Y. C. mustelae (designated $H$. mustelae as a result of this study) ATCC $43772^{\mathrm{T}}$ was isolated from the stomach of a ferret and was supplied by James Fox, Boston, Mass. $H$. mustelae NCTC 12032 was isolated in the United Kingdom. Two strains of $\boldsymbol{H}$. mustelae (strains FM1 and FM2) were supplied by Dennis Jones, Manchester, United Kingdom, and strain FPD1 was supplied by Diane Newell, Porton, United Kingdom. In Western Australia, we isolated $\boldsymbol{H}$. mustelae FP1 from a ferret. Thus, six isolates of $H$. mustelae were studied. $C$. jejuni NCTC 11351 and $W$. succinogenes NCTC $11488^{\mathrm{T}}$ were obtained from the National Collection of Type Cultures, London, United Kingdom. " $F$. rappini" 1893 was supplied by J. H. Bryner, Ames, Iowa.

The organisms were maintained on brain heart infusion agar (BHIA) (Oxoid Ltd., London, England) supplemented with $7 \%$ horse blood lysed by saponin and were incubated in vented jars containing a microaerophilic atmosphere $\left(5 \% \mathrm{O}_{2}\right.$, $7 \% \mathrm{CO}_{2}, 8 \% \mathrm{H}_{2}, 80 \% \mathrm{~N}_{2}$ ) for 2 to 3 days (21), by which time all of the strains had grown. The strains were stored at $-70^{\circ} \mathrm{C}$ in $1 \%$ peptone water containing $25 \%$ glycerol.

DNA base composition. DNAs were extracted by the Marmur method (32) with the addition of protease treatments after cell lysis by sodium dodecyl sulfate and again after ribonuclease treatment. The $\mathrm{G}+\mathrm{C}$ contents were determined by, the $T_{\mathrm{i}}$ method of Sly and co-workers (42), using a model 2600 microprocessor-controlled spectrophotometer fitted with a thermal programmer (Gilford Instrument Laboratories, Inc., Oberlin, Ohio).

DNA hybridization. DNA hybridization was performed by two methods. The nylon filter blot method (method P) was used in Perth, Australia (15). Briefly, DNA was extracted and purified as described by Majewski and Goodwin (31); samples were denatured by boiling and blotted in triplicate onto a positively charged nylon membrane (Biotrace; Gelman Sciences, Inc., Ann Arbor, Mich.), and the membranes were baked at $80^{\circ} \mathrm{C}$ for 1 to $2 \mathrm{~h}$ to immobilize the DNA. Portions $\left(50 \mathrm{ng}\right.$ ) of DNAs from $H$. pylori NCTC $11637^{\mathrm{T}}$ and H. mustelae ATCC $43772^{\mathrm{T}}$ and NCTC 12032 were labeled with $\alpha-\left[{ }^{32} \mathrm{P}\right]$ cytidine triphosphate by random priming. Nylon membranes were sealed in plastic bags, and prehybridization and hybridization were performed at $65^{\circ} \mathrm{C}$ in a shaking water bath. The membranes were air dried and autoradiographed. Radioactivity was assayed by dividing the membranes into $1-\mathrm{cm}^{2}$ pieces, each containing one DNA blot. These pieces were placed into glass vials and dissolved by adding $1-\mathrm{ml}$ portions of concentrated formic acid; $9 \mathrm{ml}$ of scintillation fluid (Instagel; Packard Instrument Co., Inc., Downer's Grove, Ill.) was added to each vial, which was then counted with a liquid scintillation counter (model 1219; LKB Instruments, Inc., Broma, Sweden). A homologous control reaction (labeled and unlabeled DNAs from the same strain) was used to represent $100 \%$ relatedness.

In Queensland, Australia, the spectrophotometric renaturation rate method for DNA hybridization (method Q) was performed as described by De Ley and co-workers (11) and modified by Huss and co-workers (26). The temperatures of renaturation were calculated by using the method of Gillis and co-workers (18) to be $68^{\circ} \mathrm{C}$ for $H$. mustelae NCTC 12032 and $66^{\circ} \mathrm{C}$ for $H$. pylori NCTC $11637^{\mathrm{T}}$. The results of the spectrophotometric method have been reported to correlate well with the results of the membrane filter method at levels of relatedness above $30 \%$, but are unreliable at levels of relatedness below $30 \%(26)$. Two hybridization methods were used to provide confirmation of our original disagreement with world experts on the species position of $H$. mustelae.

Ultrastructural studies. Cell morphology and ultrastructural features of $H$. pylori, $H$. mustelae, $W$. succinogenes, and $C$. jejuni were determined by examining shaken broth cultures. A 3-ml portion of brain heart infusion broth (Oxoid) supplemented with $10 \%$ horse serum and $0.25 \%$ yeast extract was dispensed into a 20 -ml container, which was placed in a jar with a microaerophilic atmosphere. The jar was shaken overnight, which yielded a heavy growth of bacteria in the liquid medium after $18 \mathrm{~h}$. The organisms were subcultured into fresh shaken fluid medium on two occasions, and the third culture was used to provide preparations for thin-section electron microscopy as described previously (1). The presence of an external glycocalyx in $\boldsymbol{H}$. pylori, $\boldsymbol{H}$. mustelae, $C$. jejuni, and $W$. succinogenes was investigated by using the tannic acid method in conjunction with glutaraldehyde-osmium fixation, which provides stabilization and contrast enhancement of polysaccharide-rich bacterial surface material (30). The gastric antral biopsy specimens or bacterial cultures were fixed in $2.5 \%$ cacodylate-buffered glutaraldehyde at room temperature for 2 to $24 \mathrm{~h}$. The material was then washed in $0.16 \mathrm{M}$ cacodylate buffer $(\mathrm{pH}$ 7.2) and incubated in a freshly made solution of tannic acid (laboratory no. T-0215; Sigma Chemical Co., St. Louis, Mo.) in the same buffer at $\mathrm{pH} 7.2$ for $24 \mathrm{~h}$ at $4^{\circ} \mathrm{C}$. Specimens were again washed in cacodylate buffer, and the bacterial suspensions were pelleted by centrifugation in $10 \%$ bovine serum albumin. Subsequent processing (in a Sakura model REM208B EM Processor) included postfixation with $1 \%$ osmium tetroxide, dehydration, and infiltration with epoxy resin. Thin sections were mounted on naked copper grids and viewed, after staining with uranyl acetate and lead citrate, by using a Philips model EM 410(HM) electron microscope.

Cellular fatty acid analysis. The strains of bacteria were cultured for 2 to 4 days on BIHA supplemented with $7 \%$ saponin-lysed blood; however, only if a heavy, healthy 
growth was obtained were the cells harvested and processed. Bacteria from old or poorly growing cultures tended to give variable results and were discarded. Fatty acid methyl esters were prepared and analyzed by using the method of Goodwin et al. (23). This included saponification by sodium hydroxide, methylation with sulfuric acid in methanol, extraction of the fatty acid methyl esters with hexane, and concentration under a stream of nitrogen. The samples were stored at $-20^{\circ} \mathrm{C}$ until they were analyzed by gas chromatography with a model $5890 \mathrm{~A}$ gas chromatograph (Hewlett-Packard Co., Palo Alto, Calif.) equipped with a flame ionization detector and a Hewlett-Packard model 3393A integrator. Separation was achieved on a Superox$20 \mathrm{M}$ capillary column $(0.53 \mathrm{~mm}$ by $10 \mathrm{~m})$ by using a column flow rate of $2.6 \mathrm{ml} / \mathrm{min}$, with the injector temperature at $250^{\circ} \mathrm{C}$ (to ensure efficient vaporization), the detector temperature at $250^{\circ} \mathrm{C}$, and the oven temperature at $60^{\circ} \mathrm{C}$ for $1 \mathrm{~min}$ and then increased by $5^{\circ} \mathrm{C} / \mathrm{min}$ to $200^{\circ} \mathrm{C}$, which was maintained for $10 \mathrm{~min}$. Major peaks were identified by comparison with the retention times of known standards and by mass spectroscopy. The area under each peak was calculated with the integrator to determine the percentage of each fatty acid in the sample. Extractions from the various isolates were replicated three times to ensure that the results were reproducible. We used a long temperature program to ensure that all relevant cellular fatty acids were detected.

Analysis of respiratory quinones. The method used to analyze respiratory quinones was that described by Goodwin et al. (22).

Growth conditions and enzyme capabilities. Growth at various temperatures was tested on BHIA containing 7\% horse blood, 1\% IsoVitaleX (BBL Microbiology Systems Cockeysville, Md.), and $0.25 \%$ yeast extract, and the ability to grow in the presence of air enriched with $10 \% \mathrm{CO}_{2}$ was tested in a $\mathrm{CO}_{2}$ incubator with $98 \%$ humidity. Growth was also tested on the same medium supplemented with a final concentration of $3.5 \% \mathrm{NaCl}, 0.5$ or $1 \%$ glycine, or $1 \%$ bile. In addition, growth was tested on the peptone-starch-dextrose (PSD) medium of Dunkelberg et al. (14) and on campylobacter blood-free selective agar base (2), which contains charcoal, casein, and $0.1 \%$ deoxycholate. Growth anaerobically at $37^{\circ} \mathrm{C}$ was tested in a jar that was evacuated and filled three times with a gas mixture containing $10 \%$ $\mathrm{CO}_{2}, 10 \% \mathrm{H}_{2}$, and $80 \% \mathrm{~N}_{2}$ and also in an anaerobic chamber. Failure to grow after 4 days of incubation was considered a negative result.

Urease was tested in Christensen urea broth (29); hippurate hydrolysis was tested by the method of Lennette et al. (29); nitrate production was tested by the method of Cowan and Steel (10); and $\mathrm{H}_{2} \mathrm{~S}$ production was tested in triple sugar iron agar containing $0.25 \%$ yeast extract.

Enzyme capabilities were tested by the method of Mégraud et al. (35) in a microaerophilic atmosphere. A suspension equivalent to a McFarland standard of 7 to 8 was prepared in a saline solution, and $0.1 \mathrm{ml}$ was used to inoculate each of the API ZYM microtubes (API System, La
TABLE 1. Levels of DNA relatedness of $H$. pylori and H. mustelae strains

\begin{tabular}{|c|c|c|c|c|c|}
\hline \multirow{3}{*}{ Test strain } & \multicolumn{5}{|c|}{$\%$ Relatedness to reference DNA from ${ }^{a}$ : } \\
\hline & \multirow{2}{*}{$\begin{array}{l}\text { H. mustelae } \\
\text { ATCC } \\
43772^{\mathrm{T}} \\
(\text { method P) }\end{array}$} & \multicolumn{2}{|c|}{$\begin{array}{l}\text { H. mustelae } \\
\text { NCTC } 12032\end{array}$} & \multicolumn{2}{|c|}{$\begin{array}{l}\text { H. pylori NCTC } \\
11637^{\mathrm{T}}\end{array}$} \\
\hline & & $\underset{P}{\text { Method }}$ & $\begin{array}{c}\text { Method } \\
\text { Q }\end{array}$ & $\begin{array}{c}\text { Method } \\
\mathbf{P}\end{array}$ & $\begin{array}{c}\text { Method } \\
\text { Q }\end{array}$ \\
\hline $\begin{array}{l}\text { H. mustelae ATCC } \\
43772^{\mathrm{T}}\end{array}$ & 100 & & & 7 & 30 \\
\hline $\begin{array}{l}\text { H. mustelae NCTC } \\
12032\end{array}$ & 75 & & 100 & 1 & 44 \\
\hline H. mustelae FP1 & 96 & & & 8 & \\
\hline $\begin{array}{l}\text { H. pylori NCTC } \\
11637^{\mathrm{T}}\end{array}$ & 2 & $<5$ & 49 & 100 & 100 \\
\hline
\end{tabular}

${ }^{a}$ Hybridization analyses were conducted at optimal renaturation temperatures, which were calculated by using the method of Gillis et al. (18) and were $68^{\circ} \mathrm{C}$ for strain NCTC 12032 and $66^{\circ} \mathrm{C}$ for strain NCTC $11637^{\mathrm{T}}$.

${ }^{b}$ See text for explanation of methods.

Balme les Grottes, France). Motility was determined by phase-contrast microscopy (40). To determine motility in broth, the organisms were shaken overnight in brain heart infusion broth in a microaerophilic atmosphere (1).

Antibiotic susceptibilities were determined by disk diffusion on BHIA containing $7 \%$ lysed horse blood, with incubation for 1 day for $C$. jejuni, W. succinogenes, and " $F$. rappini' and for 2 days for $H$. pylori and $H$. mustelae.

\section{RESULTS}

DNA base composition. The $\mathrm{G}+\mathrm{C}$ content of $\boldsymbol{H}$. mustelae ATCC $43772^{\mathrm{T}}$ was $36.5 \pm 0.8 \mathrm{~mol} \%$, the $\mathrm{G}+\mathrm{C}$ content of strain NCTC 12032 was $40.6 \pm 0.57 \mathrm{~mol} \%$, and the $\mathrm{G}+\mathrm{C}$ content of isolate FP1 from Western Australia was $35.9 \pm$ $0.46 \mathrm{~mol} \%$.

DNA hybridization. Table 1 shows the results determined by the filter blot and spectrophotometric hybridization methods, which indicate the levels of relatedness of the $H$. mustelae strains to one another and to $H$. pylori. In $65^{\circ} \mathrm{C}$ reactions in which the filter blot method was used, $H$. mustelae strains were 75 to $100 \%$ interrelated and exhibited 2 to $8 \%$ relatedness to $H$. pylori. When the spectrophotometric method at 66 or $68^{\circ} \mathrm{C}$ was used, $H$. pylori was 30 to $49 \%$ related to $H$. mustelae.

Ultrastructural features. The major ultrastructural features of $\boldsymbol{H}$. pylori have been described previously (24). They are summarized in Table 2 together with the features of $H$. mustelae NCTC 12032, W. succinogenes NCTC 11488, and $C$. jejuni NCTC 11351. The flagella of $H$. pylori and $H$. mustelae are multiple and sheathed and have distinctive, terminal bulbs; the cell wall is smooth, and the ends are rounded. These features are different in W. succinogenes and $C$. jejuni. In pure cultures, as well as in parallel gastric biopsy specimens, $H$. pylori and $H$. mustelae regularly exhibit a prominent electron-dense glycocalyx or capsulelike

TABLE 2. Ultrastructural features of $H$. pylori, H. mustelae, C. jejuni, and W. succinogenes

\begin{tabular}{|c|c|c|c|c|c|}
\hline Strain & $\begin{array}{c}\text { Cell wall } \\
\text { membrane }\end{array}$ & Flagella & $\begin{array}{l}\text { Flagellar } \\
\text { sheath }\end{array}$ & $\begin{array}{l}\text { Flagellar } \\
\text { bulb }\end{array}$ & $\begin{array}{c}\text { Glycocalyx } \\
\text { (in vitro in shaken broth) }\end{array}$ \\
\hline C. jejuni NCTC 11351 & Rugose & Single, bipolar & Absent & Absent & Scanty \\
\hline H. pylori NCTC $11637^{\mathrm{T}}$ & Smooth & Multiple, unipolar & Present & Present & Present \\
\hline H. mustelae NCTC 12032 & Smooth & Multiple, bipolar and lateral & Present & Present & Present \\
\hline W. succinogenes NCTC 11488 & Variable & Single, unipolar & Absent & Absent & Scanty \\
\hline
\end{tabular}



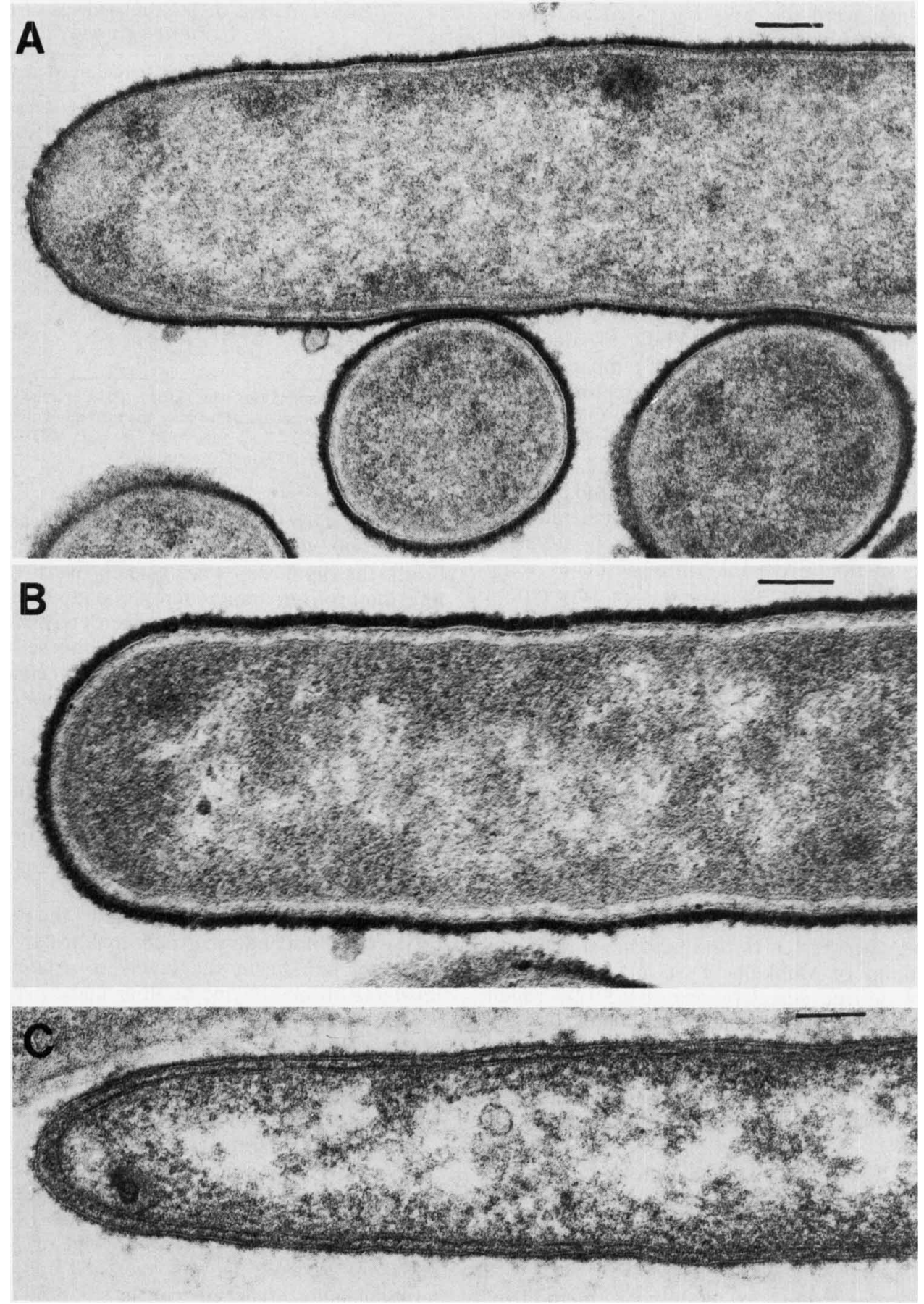

FIG. 1. Ultrastructural appearance of cultured cells of $H$. pylori $\mathrm{NCTC} 11637^{\mathrm{T}}(\mathrm{A}), H$. mustelae FM2 (B), and $W$. succinogenes NCTC 11488 (C) after processing with tannic acid for stabilization of the external polysaccharidic glycocalyces. The electron-opaque surface layer is comparatively sparse in W. succinogenes NCTC 11488. Thin-section electron microscopy. Bars $=100 \mathrm{~nm}$.

coat external to the cell wall unit membrane (Fig. 1A and B); this structure was quite inapparent in specimens processed conventionally for thin sectioning. The glycocalyx is up to 40 $\mathrm{nm}$ thick, has a radial periodicity of about $14 \mathrm{~nm}$, and is generally thicker in vivo than in cultured organisms. By comparison, W. succinogenes (Fig. $1 \mathrm{C}$ ) and $C$. jejuni have only a very scanty glycocalyx.

Cellular fatty acid analysis. The cellular fatty acid profiles of four isolates of $H$. pylori and six isolates of $H$. mustelae are shown in Table 3 . The profile of $H$. pylori is characterized by a very high percentage of $14: 0$ acid $(>35 \%)$, a low percentage of $16: 0$ acid $(<8 \%)$, and the presence of 3 OH-18:0 acid, while $H$. mustelae has a moderate concentration of 14:0 acid $(<18 \%)$, a very small amount of $15: 0$ acid $(2$ to $4 \%$ ), and a large amount of $16: 0$ acid $(>27 \%)$ but no 3-OH-18:0 acid. The profile of $W$. succinogenes indicates a very small amount of $14: 0$ acid $(<5 \%)$, a moderate amount of 16:0 acid (17\%), a very high percentage of $16: 1$ acid $(33 \%)$, 
TABLE 3. Cellular fatty acids of $H$. pylori, H. mustelae, and W. succinogenes

\begin{tabular}{|c|c|c|c|c|c|c|c|c|c|c|c|c|}
\hline \multirow[b]{2}{*}{ Strain $^{a}$} & \multicolumn{12}{|c|}{$\%$ of $^{b}:$} \\
\hline & $\begin{array}{l}12: 0 \\
\text { acid }^{c}\end{array}$ & $\begin{array}{l}\text { 14:0 } \\
\text { acid }\end{array}$ & $\begin{array}{c}3-\mathrm{OH} \\
14: 0 \\
\text { acid }\end{array}$ & $\begin{array}{l}15: 0 \\
\text { acid }\end{array}$ & $\begin{array}{l}16: 0 \\
\text { acid }\end{array}$ & $\begin{array}{l}16: 1 \\
\text { acid }\end{array}$ & $\begin{array}{c}3-\mathrm{OH} \\
16: 0 \\
\text { acid }\end{array}$ & $\begin{array}{l}18: 0 \\
\text { acid }\end{array}$ & $\begin{array}{l}18: 1 \\
\text { acid }\end{array}$ & $\begin{array}{l}18: 2 \\
\text { acid }\end{array}$ & $\begin{array}{c}3-\mathrm{OH} \\
18: 0 \\
\text { acid }\end{array}$ & $\begin{array}{l}19: 0 \\
\text { cyc } \\
\text { acid }\end{array}$ \\
\hline \multicolumn{13}{|l|}{ H. pylori strains } \\
\hline NCTC $11637^{\mathrm{T}}$ & $\mathrm{T}$ & 41 & - & - & 5 & $\mathrm{~T}$ & 5 & 5 & 16 & 4 & 2 & 17 \\
\hline NCTC 11638 & $\mathbf{T}$ & 41 & - & - & 7 & - & 5 & 7 & 9 & 2 & 3 & 16 \\
\hline Q188 & $\mathrm{T}$ & 37 & - & $\mathrm{T}$ & 5 & $\mathrm{~T}$ & 5 & 8 & 17 & 3 & 2 & 17 \\
\hline $72 \mathrm{R}$ & $\mathrm{T}$ & 36 & - & - & 6 & $\mathrm{~T}$ & 7 & 11 & 17 & 2 & 3 & 17 \\
\hline \multicolumn{13}{|l|}{ H. mustelae strains } \\
\hline NCTC 12032 & $\mathrm{~T}$ & 15 & - & 2 & 32 & - & 2 & $\mathbf{T}$ & 23 & 7 & - & 15 \\
\hline ATCC $47332^{\mathrm{T}}$ & - & 13 & - & 2 & 30 & - & 2 & $\mathrm{~T}$ & 17 & 5 & - & 16 \\
\hline Ferret MI & $\mathbf{T}$ & 17 & - & 3 & 28 & - & 4 & $\mathbf{T}$ & 17 & 9 & - & 13 \\
\hline Ferret PD1 & - & 15 & - & 3 & 36 & - & 2 & 5 & 23 & 6 & - & 10 \\
\hline Ferret M2 & $\mathrm{T}$ & 14 & - & 4 & 29 & - & 2 & 3 & 14 & 7 & - & 8 \\
\hline Ferret P1 & $\mathrm{T}$ & 14 & - & 2 & 34 & - & 2 & $\mathrm{~T}$ & 23 & 5 & - & 15 \\
\hline $\begin{array}{r}\text { W. succinogenes } \\
\text { NCTC } 11488\end{array}$ & 5 & 3 & $\mathrm{~T}$ & $\mathrm{~T}$ & 17 & 33 & $\mathrm{~T}$ & $\mathrm{~T}$ & 28 & 9 & - & - \\
\hline
\end{tabular}

${ }^{a}$ ATCC, American Type Culture Collection, Rockville, Md.; NCTC, National Collection of Type Cultures, Central Public Health Laboratory, London, England.

${ }_{b}^{b}$ Values are percentages of total fatty acids and are arithmetic means. -, Not detected or less than $0.5 \% ;, 0.5$ to $1.9 \%$.

c Number of carbon atoms: number of double bonds. cyc, Cyclopropane fatty acid; 3-OH, hydroxy group at carbon 3.

and no 3-OH-18:0 or 19:0 cyc acid. This profile is clearly different from the profiles of $H$. pylori and $H$. mustelae.

Respiratory quinones. $H$. pylori possesses only MK-6 and lacks the methylated MK-6 (22) which is found in all campylobacters (7) and also in $W$. succinogenes at a level of 20 to $50 \%(8)$. We found that $H$. mustelae NCTC 12032 possesses a small amount (5\%) of methylated MK-6 and that " $F$. rappini" 1893 does not possess methylated MK-6.
Growth conditions and enzyme capabilities. In Table 4 the major biochemical characteristics of $\boldsymbol{H}$. pylori and $\boldsymbol{H}$. mustelae are compared with those of $C$. jejuni, W. succinogenes, and " $F$. rappini". W. succinogenes was catalase and urease negative, which differentiates this species from $H$. pylori and $H$. mustelae. W. succinogenes was a weak producer of $\mathrm{H}_{2} \mathrm{~S}$ in triple sugar iron agar, but $H$. pylori and $H$. mustelae were not. W. succinogenes lacked gamma-glutamyltranspeptidase

TABLE 4. Biochemical and cultural characteristics of $C$. jejuni, H. pylori, H. mustelae, W. succinogenes, and " $F$. rappini”

\begin{tabular}{|c|c|c|c|c|c|}
\hline Characteristic & $\begin{array}{l}\text { C. jejuni } \\
\text { NCTC } 11351\end{array}$ & $\begin{array}{c}\text { H. pylori } \\
\text { NCTC } 11637^{\mathrm{T}}\end{array}$ & $\begin{array}{l}\text { H. mustelae } \\
\text { NCTC } 12032\end{array}$ & $\begin{array}{l}W . \text { succinogenes } \\
\text { NCTC } 11488\end{array}$ & $\begin{array}{l}\text { "F. rappini" } \\
1893\end{array}$ \\
\hline Oxidase & $+^{a}$ & + & + & + & + \\
\hline Catalase & + & + & + & - & + \\
\hline Urease & - & + & + & - & + \\
\hline Hippurate hydrolysis & + & - & - & - & - \\
\hline Nitrate reduction (microaerophilic) & + & - & + & + & - \\
\hline $\mathrm{H}_{2} \mathrm{~S}$ production in triple sugar iron agar & - & - & - & W & - \\
\hline Gamma-glutamyltranspeptidase & - & + & + & - & + \\
\hline Alkaline phosphatase & W & + & + & - & - \\
\hline Motility in brain heart infusion broth & + & + & + & + & + \\
\hline Motility from agar plate & + & - & - & - & - \\
\hline \multicolumn{6}{|l|}{ Growth microaerophilically at: } \\
\hline $25^{\circ} \mathrm{C}$ & $-(2)^{b}$ & $-(4)$ & $-(4)$ & $-(2)$ & $-(2)$ \\
\hline $30^{\circ} \mathrm{C}$ & $+(1)$ & $+(2)$ & $+(2)$ & $-(2)$ & $-(2)$ \\
\hline $37^{\circ} \mathrm{C}$ & $+(1)$ & $+(2)$ & $+(2)$ & $+(1)$ & $+(1)$ \\
\hline $42^{\circ} \mathrm{C}$ & $+(1)$ & $-(4)$ & $+(2)$ & $\mathrm{W}(2)$ & $+(1)$ \\
\hline Growth in $\mathrm{CO}_{2}$ inhibitor & $+(1)$ & $+(2)$ & $-(4)$ & $-(2)$ & $-(2)$ \\
\hline Growth anaerobically at $37^{\circ} \mathrm{C}$ & + & - & $\mathrm{W}$ & + & + \\
\hline Growth on blood agar containing $3.5 \% \mathrm{NaCl}$ & - & - & - & - & - \\
\hline Growth on $0.5 \%$ glycine & + & + & + & - & + \\
\hline Growth on $1 \%$ glycine & + & - & + & - & W \\
\hline Growth on $1 \%$ bile & + & - & - & + & + \\
\hline Growth on PSD & + & + & - & + & + \\
\hline $\begin{array}{l}\text { Growth on charcoal-Casein- }-1 \% \\
\text { deoxycholate }\end{array}$ & + & - & - & + & - \\
\hline Susceptibility to nalidixic acid (30- $\mu$ g disk) & $S$ & $\mathbf{R}$ & $\mathbf{S}$ & $\mathbf{R}$ & $\mathbf{R}$ \\
\hline Susceptibility to cephalothin $(30-\mu \mathrm{g}$ disk $)$ & $\mathbf{R}$ & $\mathbf{S}$ & $\mathbf{R}$ & $\mathbf{R}$ & $\mathbf{R}$ \\
\hline Susceptibility to metronidazole (5- $\mathrm{gg}$ disk) & $\mathbf{R}$ & $\mathbf{S}$ & $\mathbf{S}$ & $\mathbf{S}$ & $\mathbf{R}$ \\
\hline
\end{tabular}

${ }^{a}+$, Positive; - , negative; $\mathbf{W}$, weak; $\mathrm{S}$, susceptible; $\mathbf{R}$, resistant.

$b$ The numbers in parentheses are numbers of days. 
and alkaline phosphatase, which were possessed by $H$. pylori and $H$. mustelae. W. succinogenes failed to grow at $30{ }^{\circ} \mathrm{C}$ and on $0.5 \%$ glycine, whereas $H$. pylori and $H$. mustelae grew at $30^{\circ} \mathrm{C}$ and on $0.5 \%$ glycine. $W$. succinogenes grew on BHIA supplemented with $1 \%$ bile and on the campylobacter-selective medium (2) containing charcoal, casein, and $0.1 \%$ deoxycholate; $H$. pylori NCTC $11637^{\mathrm{T}}$ and $H$. mustelae NCTC 12032 failed to grow on these media. We found that $W$. succinogenes was oxidase positive, although in the original description this species was defined as oxidase negative (43).

The number of strains tested to determine the biochemical features of $H$. pylori (Table 4) varied between 25 and 78 strains, and in each test all of the isolates gave the same reaction. We have reported previously (31) that when four strains were repeatedly subcultured in semisolid agar over many months and years, they lost their urease activity and that two isolates lost their catalase activity. We found that these urease-negative strains (including strain Q188 [Table 3]) were able to grow on $1 \%$ bile. The six strains of $H$. mustelae were tested for each of the biochemical differences. All of the isolates gave the same reaction with the following exceptions: only one strain showed growth in air enriched with $\mathrm{CO}_{2}$, and five strains grew on $1 \%$ bile; strain NCTC 12032 failed to grow on bile (Table 4). None of the strains grew on PSD agar, in contrast to $H$. pylori. One strain of $H$. mustelae lost its urease activity (strain FM1), and three other strains showed much weaker urease activity after relatively few subcultures. $H$. mustelae grew only weakly in an anaerobic jar, but grew well in the anaerobic chamber, which could not be guaranteed to be oxygen free.

\section{DISCUSSION}

Recently, Fox and co-workers (17) described the ferret gastric organism as a new subspecies, $C$. pylori subsp. mustelae. However, in Western Australia we found that the level of DNA-DNA hybridization between $H$. pylori and the ferret organism was less than $15 \%$ at $65^{\circ} \mathrm{C}$. We exchanged strains with D. J. Brenner at the Centers for Disease Control, Atlanta, Ga., who subsequently agreed with our findings, and the ferret organism has been elevated to species status as $C$. mustelae (15). Other major taxonomic features of the ferret organism are consistent with its designation as a species separate from $H$. pylori. Ultrastructurally, $H$. mustelae is shorter than $H$. pylori and has both bipolar and lateral flagella (Table 2 ); $H$. pylori has only unipolar flagella. The cellular fatty acid profile of $H$. mustelae contains a lower percentage of 14:0 acid and a greater percentage of 16:0 acid than the profile of $H$. pylori (Table 3). The latter species contains 3-OH-18:0 acid, as originally reported by Lambert and co-workers (27). Differences in growth characteristics and enzyme capabilities between $\boldsymbol{H}$. pylori and $H$. mustelae (Table 4) include nitrate reduction by $H$. mustelae and not by $H$. pylori. $H$. pylori grows on PSD agar and in air enriched with $\mathrm{CO}_{2}$, but not anaerobically and variably at $42^{\circ} \mathrm{C}$. H. mustelae does not grow on PSD agar or in air enriched with $\mathrm{CO}_{2}$, but grows well at $42^{\circ} \mathrm{C}$ and weakly in an anaerobic atmosphere. $H$. pylori is susceptible to cephalothin, but most strains are resistant to nalidixic acid, while $H$. mustelae is susceptible to nalidixic acid and resistant to cephalothin. Tompkins and co-workers (45) reported that $\boldsymbol{H}$. mustelae fails to grow anaerobically, but all six of our strains grew anaerobically.
The phylogenetic position of $H$. pylori, as determined by 16S ribosomal ribonucleic acid sequencing, clearly indicates that this species should be excluded from the genus Campylobacter $(28,38,41,44)$. Ribosomal ribonucleic acid sequencing has also indicated that $H$. pylori is closely related to $W$. succinogenes; Thompson et al. have suggested that $H$. pylori should be transferred to the genus Wolinella (44). However, Romaniuk et al. (41) and Lau et al. (28) noted significant differences between $W$. succinogenes and $H$. pylori and concluded that these organisms should be in separate genera. Computerized ribonucleic acid data can be handled in at least two different ways; one yields a simple dendrogram, such as the dendrogram of Thompson et al. (44), but a more sophisticated "treeing" calculation might indicate that $H$. pylori is not closely related to $W$. succinogenes. Owen (37) identified 14 phenotypic differences between $H$. pylori and $W$. succinogenes and argued cogently that these species should be in separate genera. In this study we delineated five major groups of taxonomic features which clearly differentiate $H$. pylori and $H$. mustelae from $W$. succinogenes and $C$. jejuni. These features were also considered important by the Subcommittee for Taxonomy of Methanogenic Bacteria (3); they are ultrastructural features, cellular fatty acid profiles, respiratory quinones, growth characteristics, and enzyme capabilities. We suggest that a premature decision to assign $H$. pylori to the genus Wolinella would result in that genus being the home of a very diverse group of bacteria. The removing of diversity from one genus by introducing it into another would not be the solution to the taxonomic problems of $\boldsymbol{H}$. pylori and $H$. mustelae; thus, the concept of a new genus seems to be the most reasonable strategy at this time (J. L. Penner, personal communication). Reclassification now seems fully justified and necessary.

Brenner (4) has stated that "phenotype should take precedence over DNA relatedness at the genus level. Even if one can arrive at a genetic definition for genus (I doubt that one can, since genus is a synthetic ranking that was designed for convenience), the primary consideration for a genus is that it contain biochemically similar species, that are convenient or important to consider as a group, and that must be separated from one another at the bench." There are many differences in biochemical features and growth characteristics between $H$. pylori and W. succinogenes (Table 4), which indicate that these species should not be in the same genus. $W$. succinogenes is catalase negative and urease negative, whereas $\boldsymbol{H}$. pylori and $\boldsymbol{H}$. mustelae are catalase positive and urease positive. W. succinogenes does not possess gammaglutamyltranspeptidase or alkaline phosphatase, which are possessed by $H$. pylori and $H$. mustelae. W. succinogenes does not grow at $30^{\circ} \mathrm{C}$ or on $0.5 \%$ glycine, but grows on charcoal-casein-0.1\% deoxycholate; $H$. pylori and $H$. mustelae have exactly the opposite characteristics.

Paster and Dewhirst (38) have argued that differences in DNA $G+C$ contents should not be a primary consideration for excluding species from the same genus, and we agree. These authors emphasized the importance of methylated MK-6 to campylobacters and stated that it is a valuable chemotaxonomic marker; $W$. succinogenes contains this menaquinone, while $H$. pylori does not.

We conclude that these phenotypic differences outweigh at the genus level the genomic relatedness suggested by $16 \mathrm{~S}$ ribosomal ribonucleic acid sequencing and justify the transfer of $\boldsymbol{H}$. pylori and $\boldsymbol{H}$. mustelae to a new genus.

" $F$. rappini" is another organism which is urease positive and possibly genomically closely related to $H$. pylori. However, it is a straight organism, not a spiral organism, with 
marked periplasmic fibers, and a $\mathrm{G}+\mathrm{C}$ content of $33 \mathrm{~mol} \%$, and it grows at $43^{\circ} \mathrm{C}$ (Bryner, Campylobacter IV. Proc. 4th Int. Workshop Campylobacter Infect.). These characteristics are quite different than those of $H$. pylori and $H$. mustelae. Table 4 shows the biochemical differences between "F. rappini" and $H$. pylori and $H$. mustelae. " $F$. rappini" does not possess alkaline phosphatase or grow at $30^{\circ} \mathrm{C}$, whereas $H$. pylori and $H$. mustelae possess this enzyme and grow at $30^{\circ} \mathrm{C}$. " $F$. rappini" is resistant to metronidazole $(5 \mu \mathrm{g})$, whereas the other two organisms are susceptible.

In conclusion, the low degree of relatedness between $H$. pylori and any previously described genus except the genus Wolinella, together with the possession of a set of chemotaxonomic properties different from those of the genus $\mathrm{Wo}$ linella and neighboring taxa, provides a strong case for the designation of this organism as the type species of a new genus, which we name Helicobacter, with Helicobacter pylori comb. nov. as the type species. Spiral organisms identified as $H$. pylori have been isolated from the stomachs of rhesus monkeys, $M$. mulatta (36), and $M$. nemestrina (5). We have determined that the DNA base composition of the organism from $M$. nemestrina is $44 \mathrm{~mol} \% \mathrm{G}+\mathrm{C}$, and therefore we include this value in the $\mathrm{G}+\mathrm{C}$ range for the genus Helicobacter. The significance of bacterial polysaccharidic glycocalyces in microbial-host interactions, whether pathogenic or autocthonous, has been comprehensively reviewed previously (9). The presence of a glycocalyx is revealed ultrastructurally after stabilization with either ruthenium red (9) or tannic acid (30), but the latter method gives higher contrast enhancement. The thick glycocalyces of $H$. pylori and of $H$. mustelae are important structural features of the organisms, although their chemical compositions have yet to be determined precisely. Organisms grown on solid media rarely produce a glycocalyx.

Description of Helicobacter Goodwin et al. gen. nov. Helicobacter. (He. li. co. bac' ter; Gr. n. helix, a spiral; N. L. masc. n. bacter, a staff; N. L. masc. n. Helicobacter, a spiral rod). Helical, curved, or straight unbranched cells, 2.5 to 5 $\mu \mathrm{m}$ long and 0.5 to $1.0 \mu \mathrm{m}$ wide, having rounded ends and spiral periodicity (23). External glycocalyx produced in vitro in shaken broth cultures. Gram negative, microaerophilic. Rapid, darting motility by means of multiple sheathed flagella that are unipolar or bipolar and lateral, with terminal bulbs. Endospores are not produced. Slow growth in brain heart infusion broth and other liquid media unless shaken; growth in 2 to 5 days on brain heart infusion blood agar and chocolate agar. Growth also occurs on BHIA supplemented with charcoal or corn starch (6).

Colonies are nonpigmented, translucent, and 1 to $2 \mathrm{~mm}$ in diameter $(5,6,34,36)$. Optimal growth at $37^{\circ} \mathrm{C}$; growth at $30^{\circ} \mathrm{C}$ but not at $25^{\circ} \mathrm{C}$; variable growth at $42^{\circ} \mathrm{C}$. Variable growth in air enriched with $10 \% \mathrm{CO}_{2}$ and anaerobically. No growth in the presence of $3.5 \% \mathrm{NaCl}$. Growth in the presence of $0.5 \%$ glycine and $0.04 \%$ triphenyltetrazolium chloride. Catalase and oxidase positive. Urea is rapidly hydrolyzed. The major isoprenoid quinone is MK-6; variable possession of methylated $\mathrm{MK}-6 . \mathrm{H}_{2} \mathrm{~S}$ production is negative on triple sugar iron agar and variable on lead acetate paper. Variable reactions for nitrate reduction and hippurate hydrolysis. Exhibits alkaline phosphatase and gammaglutamyltranspeptidase activities; variable leucine arylamidase activity (35). Susceptible to penicillin, ampicillin, amoxicillin, erythromycin, gentamicin, kanamycin, penicillin, rifampin, and tetracycline (20). Resistant to vancomycin, sulfonamides, and trimethoprim. Variable resistance to na- lidixic acid, cephalothin, metronidazole, and polymyxin (12). $\mathrm{G}+\mathrm{C}$ content, 35 to $44 \mathrm{~mol} \%$ (melting temperature method).

Isolated from the gastric mucosa of primates and ferrets, and some organisms in the genus may be associated with gastritis and peptic ulceration. The type species is Helicobacter pylori (Marshall et al., 1984) comb. nov.

Description of Helicobacter pylori comb. nov. Helicobacter pylori (basionym, Campylobacter pylori Marshall and Goodwin, 1987) (py. lo' ri. Gr. masc. n. pyloros, gate keeper; L. masc. n. pylorus, lower part of the stomach; L. gen. $\mathrm{n}$. pylori, of the pylorus). Four to six unipolar flagella. In addition to the characteristics described above, $H$. pylori has a $\mathrm{G}+\mathrm{C}$ content of 36 to $38 \mathrm{~mol} \%$ (34). Growth in the presence of air enriched with $10 \% \mathrm{CO}_{2}$ and on PSD agar. No growth anaerobically at $37^{\circ} \mathrm{C}$ or on $1 \%$ glycine. The cellular fatty acid profile includes $3-\mathrm{OH} 18: 0$ acid, more than $35 \%$ $14: 0$ acid, less than $10 \% 16: 0$ acid, and more than $4 \% 3-\mathrm{OH}$ 16:0 acid (27). Does not reduce nitrates. Susceptible to cephalothin $(30 \mu \mathrm{g})$. Isolated from the gastric mucosa of primates. Found in human cases of gastritis and gastric and duodenal ulcers. Causative for type B gastritis; the role of this organism in duodenal ulceration is probably as a predisposing cause, not a precipitating cause $(19,25)$. The type strain is Royal Perth Hospital isolate 13487 (= NCTC 11637 $=$ ATCC 43504), which has a $\mathrm{G}+\mathrm{C}$ content of $37.1 \mathrm{~mol} \%$ (34).

Deseription of Helicobacter mustelae comb. nov. Helicobacter mustelae (basionym, Campylobacter mustelae Fox et al., 1989) (mus. tel' ae. L. gen. n. mustelae, of a ferret). Lateral and bipolar flagella. In addition to the genus characteristics described above, the $\mathrm{G}+\mathrm{C}$ content is 35 to $41 \mathrm{~mol} \%$. The cellular fatty acid profile includes less than $18 \% 14: 0$ acid, more than 25\% 16:0 acid, and no 3-OH 18:0 acid. Grows at $42^{\circ} \mathrm{C}$ microaerophilically and anaerobically with $\mathrm{CO}_{2}$ at $37^{\circ} \mathrm{C}$. No growth in air enriched with $10 \% \mathrm{CO}_{2}$ or on PSD agar. Variable growth on $1 \%$ glycine (17). Reduces nitrates. Susceptible to nalidixic acid $(30 \mu \mathrm{g})$ but resistant to cephalothin $(30 \mu \mathrm{g})$. Does not exhibit leucine arylamidase activity (45). Isolated from the gastric mucosa of ferrets. Causes gastritis and peptic ulceration in adult animals. The type strain is strain R85-13-6 (= ATCC 43772) (15), which has a $\mathrm{G}+\mathrm{C}$ content of $35.5 \pm 0.8 \mathrm{~mol} \%$.

\section{ACKNOWLEDGMENTS}

We thank Thomas Ozro MacAdoo, Department of Languages and Literature, Virginia Polytechnic Institute and State University, Blacksburg, for his expert advice on latinization of names. We thank John Bowman, Vullapa Arunpairajana, and Julian Cox for assistance with the determination of DNA base ratios and DNA hybridization and Rowena Evans for typing the manuscript.

This study was supported in part by the Royal Perth Hospital Research Foundation.

\section{LITERATURE CITED}

1. Armstrong, J. A., S. H. Wee, C. S. Goodwin and D. H. Wilson. 1987. Response of Campylobacter pyloridis to antibiotics, bismuth and an acid-reducing agent in vitro-an ultrastructural study. J. Med. Microbiol. 24:343-350.

2. Bolton, F. J., and L. Robertson. 1982. A selective medium for isolating Campylobacter jejuni/coli. J. Clin. Pathol. 35:462-467.

3. Boone, D. R., and W. B. Whitman. 1988. Proposal of minimal 
standards for describing new taxa of methanogenic bacteria. Int. J. Syst. Bacteriol. 38:212-219.

4. Brenner, D. J. 1983. Impact of modern taxonomy on clinical microbiology. ASM News 49:58-63.

5. Bronsdon, M. A., and F. D. Schoenknecht. 1988. Campylobacter pylori isolated from the stomach of the monkey Macaca nemestrina. J. Clin. Microbiol. 26:1725-1728.

6. Buck, G. E., and J. S. Smith. 1987. Medium supplementation for growth of Campylobacter pyloridis. J. Clin. Microbiol. 25: 597-599.

7. Collins, M. D., M. Costas, and R. J. Owen. 1984. Isoprenoid quinone composition of representatives of the genus Campylobacter. Arch. Microbiol. 137:168-170.

8. Collins, M. D., and F. Fernandez. 1984. Menaquinone-6 and thermoplasmaquinone-6 in Wolinella succinogenes. FEMS Microbiol. Lett. 22:273-276.

9. Costerton, J. W., R. T. Irvin, and K. J. Cheng. 1981. The role of bacterial surface structures in pathogenesis. Crit. Rev. Microbiol. 8:303-308.

10. Cowan, S. T., and K. J. Steel. 1965. Manual for the identification of medical bacteria, p. 121. Cambridge University Press, Cambridge.

11. De Ley, J., H. Cattoir, and A. Reynaerts. 1970. The quantitative measurement of hybridization from renaturation rates. Eur. J. Biochem. 12:133-142.

12. Dent, J. C., and C. A. M. McNulty. 1988. Evaluation of a new selective medium for Campylobacter pylori. Eur. J. Clin. Microbiol. Infect. Dis. 7:555-558.

13. Dooley, C. P., and H. Cohen. 1988. The clinical significance of Campylobacter pylori. Ann. Intern. Med. 108:70-79.

14. Dunkelberg, W. E., R. Skaggs, and D. S. Kellogg. 1970. Method for isolation and identification of Corynebacterium vaginale (Haemophilus vaginalis). Appl. Microbiol. 19:47-52.

15. Fox, J. G., T. Chilvers, C. S. Goodwin, N. S. Taylor, P. Edmonds, L. I. Sly, and D. J. Brenner. 1989. Campylobacter mustelae, a new species resulting from the elevation of $\mathrm{Cam}$ pylobacter pylori subsp. mustelae to species status. Int. J. Syst. Bacteriol. 39:301-303.

16. Fox, J. G., B. M. Edrise, E. B. Cabot, C. Beaucage, J. C. Murphy, and K. S. Prostak. 1986. Campylobacter-like organisms isolated from gastric mucosa in ferrets. Am. J. Vet. Res. 47:236-239.

17. Fox, J. G., N. S. Taylor, P. Edmonds, and D. J. Brenner. 1988. Campylobacter pylori subsp. mustelae subsp. nov. isolated from the gastric mucosa of ferrets (Mustela putorius furo), and an emended description of Campylobacter pylori. Int. J. Syst. Bacteriol. 38:367-370.

18. Gillis, M. M., J. De Ley, and M. De Cleene. 1970. The determination of molecular weight of bacterial genome DNA from renaturation rates. Eur. J. Biochem. 12:143-153.

19. Goodwin, C. S. 1988. Duodenal ulcer, Campylobacter pylori, and the "leaking roof" concept. Lancet ii:1467-1469.

20. Goodwin, C. S., P. Blake, and E. Blincow. 1986. The minimum inhibitory and bactericidal concentrations of antibiotics and anti-ulcer agents against Campylobacter pyloridis. J. Antimicrob. Chemother. 17:309-314.

21. Goodwin, C. S., E. D. Blincow, J. R. Warren, T. E. Waters, C. R. Sanderson, and L. Easton. 1985. Evaluation of cultural techniques for isolating Campylobacter pyloridis from endoscopic biopsies of gastric mucosa. J. Clin. Pathol. 38:1127-1131.

22. Goodwin, C. S., M. D. Collins, and E. Blincow. 1986. The absence of thermoplasmaquinones in Campylobacter pyloridis, and its temperature and $\mathrm{pH}$ growth range. Microbios Lett. 32:137-140.

23. Goodwin, C. S., W. McConnell, R. K. McCulloch, C. McCullough, R. Hill, M. A. Bronsdon, and G. Kasper. 1989. Cellular fatty acid composition of Campylobacter pylori from primates and ferrets compared with those of other campylobacters. J. Clin. Microbiol. 27:938-943.

24. Goodwin, C. S., R. K. McCulloch, J. A. Armstrong, and S. H. Wee. 1985. Unusual cellular fatty acids and distinctive ultrastructure in a new spiral bacterium (Campylobacter pyloridis) from the human gastric mucosa. J. Med. Microbiol. 19:257-267.
25. Graham, D. Y. 1989. Campylobacter pylori and peptic ulcer disease. Gastroenterology 96:615-625.

26. Huss, V. A. R., H. Festl, and K. H. Schleifer. 1983. Studies on the spectrophotometric determination of DNA hybridisation from renaturation rates. Syst. Appl. Microbiol. 4:184-192.

27. Lambert, M. A., C. M. Patton, T. J. Barrett, and C. W. Moss. 1987. Differentiation of Campylobacter and Campylobacter-like organism by cellular fatty acid composition. J. Clin. Microbiol. 25:706-713.

28. Lau, P. P., B. DeBrunner-Vossbrinck, B. Dunn, K. Miotto, M. T. MacDonnell, D. M. Rollins, C. J. Pillidge, R. B. Hespell, R. R. Colwell, S. L. Mitchell, and G. E. Fox. 1987. Phylogenetic diversity and position of the genus Campylobacter. Syst. Appl. Microbiol. 9:231-238.

29. Lennette, E. H., A. Balows, W. J. Hausler, Jr., and H. J. Shadomy. 1985. Manual of clinical microbiology, 4th ed. American Society for Microbiology, Washington, D.C.

30. Lounatmaa, K. 1985. Electron microscopic methods for the study of bacterial surface structures, p. 244-260. In T. K. Korhonen, E. A. Dawes, and P. H. Makela (ed.), Enterobacterial surface antigens: methods for molecular characterisation. Elsevier, Amsterdam.

31. Majewski, S. I. H., and C. S. Goodwin. 1988. Restriction endonuclease analysis of the genome of Campylobacter pylori with a rapid extraction method: evidence for considerable genomic variation. J. Infect. Dis. 157:465-471.

32. Marmur, J. 1961. A procedure for the isolation of deoxyribonucleic acid from micro-organisms. J. Mol. Biol. 3:208-218.

33. Marshall, B. J., and C. S. Goodwin. 1987. Revised nomenclature of Campylobacter pyloridis. Int. J. Syst. Bacteriol. 37:68.

34. Marshall, B. J., H. Royce, D. I. Annear, C. S. Goodwin, J. W. Pearman, J. R. Warren, and J. A. Armstrong. 1984. Original isolation of Campylobacter pyloridis from human gastric mucosa. Microbios Lett. 25:83-88.

35. Mégraud, F., F. Bonnet, M. Garnier, and H. Lamouliatte. 1985. Characterization of "Campylobacter pyloridis"' by culture, enzymatic profile, and protein content. J. Clin. Microbiol. 22: 1007-1010.

36. Newell, D. G., and A. Baskerville. 1988. Isolation of a gastric campylobacter-like organism from the stomach of four Rhesus monkeys, and identification as Campylobacter pylori. J. Med. Microbiol, 27:41-44.

37. Owen, R. J. 1989. Taxonomy of Campylobacter pylori, p. 12-23. In B. J. Rathbone and R. V. Heatley (ed.), Campylobacter pylori and gastroduodenal disease. Blackwell Scientific Publications, Oxford.

38. Paster, B. J., and F. E. Dewhirst. 1988. Phylogeny of campylobacters, wolinellas, Bacteroides gracilis, and Bacteroides ureolyticus by $16 \mathrm{~S}$ ribosomal ribonucleic acid sequencing. Int. J. Syst. Bacteriol. 38:56-62.

39. Penner, J. L. 1988. The genus Campylobacter: a decade of progress. Clin. Microbiol. Rev. 1:157-172.

40. Pinkard, K. J., B. Harrison, J. A. Capstick, G. Medley, and J. R. Lambert. 1986. Detection of Campylobacter pyloridis in gastric mucosa by phase contrast microscopy. J. Clin. Pathol. 39: 112-113.

41. Romaniuk, P. J., B. Zoltowaska, T. J. Trust, D. J. Lane, G. J. Olsen, N. R. Pace, and D. A. Stahl. 1987. Campylobacter pylori, the spiral bacterium associated with human gastritis, is not a true Campylobacter spp. J. Bacteriol. 169:2137-2141.

42. Sly, L. I., L. L. Blackall, P. C. Kraat, T.-S. Tao, and V. Sanghobol. 1986. The use of second derivative plots for the determination of mol\% guanine plus cytosine of DNA by the thermal denaturation method. J. Microbiol. Methods 5:139156.

43. Tanner, A. C. R., S. Badger, C. H. Lie, M. A. Listgarten, R. A. Visconti, and S. S. Socransky. 1981. Wolinella gen. nov., Wolinella succinogenes (Vibrio succinogenes Wolin et al.) comb. nov., and description of Bacteroides gracilis sp. nov., Wolinella recta $\mathrm{sp}$. nov., Campylobacter concisus sp. nov., and Eikenella corrodens from humans with periodontal disease. Int. J. Syst. Bacteriol. 31:432-445.

44. Thompson, L. M., R. M. Smibert, J. L. Johnson, and N. Kreig. 
1988. Phylogenetic study of the genus Campylobacter. Int. J. Syst. Bacteriol. 38:190-200.

45. Tompkins, D. S., J. I. Wyatt, B. J. Rathbone, and A. P. West. 1988. The characterization and pathological significance of gastric campylobacter-like organisms in the ferret: a model for chronic gastritis? Epidemiol. Infect. 101:269-278.
46. Wayne, L. G., D. J. Brenner, R. R. Colwell, P. A. D. Grimont, O. Kandler, M. I. Krichevsky, L. H. Moore, W. E. C. Moore, R. G. E. Murray, E. Stackebrandt, M. P. Starr, and H. G. Truper. 1987. Report of the Ad Hoc Committee on Reconciliation of Approaches to Bacterial Systematics. Int. J. Syst. Bacteriol. 37:463-464. 